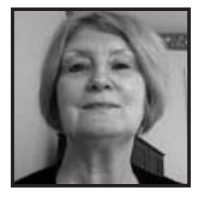

\title{
Moving Into the Dance: Exploring Facets of Student Engagement
}

\author{
Carolyn Sturge Sparkes, Education Consultant
}

\begin{abstract}
In this article the various dimensions of student engagement are examined. Based on understandings derived from her doctoral research, the author shows how engagement is realized through various levels of participation identified as assigned participation, shared participation and participative tone. She demonstrates that to enhance any theoretical explanation of engagement, one must include or "invite in" those being observed. The voices of students enrich the dialogue about how to define engagement. More importantly, the students articulate what needs to be done to make learning meaningful for them.
\end{abstract}

\section{Prologue}

$1 / 1$

o way, NO WAY are you going to catch me dancing," he declared in a clenched whisper audible to those around him, including me. Amid the embarrassed laughter around him, he grudgingly edged his way towards the stage. His body said it all. He skulked across the floor to a group of males already forming a reluctant row at the back. He slipped behind the group as if to make himself disappear.

Nathalie stood in front of them, eloquent and serene. Her stance spoke of a dancer well rehearsed and tuned for the task awaiting her. As she moved into the steps of the Baroque saraband, the students looked at her quizzically. Curiosity got the better of them. They were intrigued, as she, without apology, guided them through the choreography. 
Denis sat at the front of the stage. His fingers glided over the fingerboard of his cello. Strains of Bach filled the auditorium. The music spoke of another time, yet was forever timeless. Nathalie took the cues from his playing. The students, in turn, took their cues from her. They followed, some with cumbersome half-hearted steps, as she led them. The student-who moments ago had declared his resistance to anyone who cared to listen-hesitated, took one step, then another. Caught in a sea of pirouettes and turns, he danced ... he danced.

\section{Introduction}

In this paper I will explore the many facets of engagement: what it is and what it looks like, particularly through the eyes of students. Smithrim and Upistis (2005) refer to engagement as "being wholly involved." The word "engagement," they elaborate, is derived from the French word engagé, which, when used to describe a writer or artist means morally committed (p. 124). In my research, I conclude that engagement is participation that is "more than an action." It is "an emotional attachment and investment" (Sturge Sparkes, 2005, p. 276). Engagement implies, or suggests, an intensity of participation. Engagement is also, I surmise, context-bound. What may appear as engagement in one situation does not necessarily appear as engagement in another (p. 76). Vibert and Shields (2003) further expand on this notion by describing engagement as involvement in schooling that is a point well along "a continuum, ranging from relatively rational and technical approaches those that are more constructivist, to those reflecting a critical democratic world view" ( $p$. 237). Defining the word engagement is an interesting exercise, far more complicated than it initially appears. For purposes of this paper, I will not be focusing on engagement from a theoretical perspective, although as any researcher knows, theory is always there. Rather, I will examine engagement through the eyes of students. I will build my argument primarily upon findings generated from my doctoral research conducted a few years ago. I will also weave into my writing observations from more recent interactions with students as exemplified in the vignette described in the prologue. 


\section{Situating My Study}

\section{Study Site}

The primary site for my initial inquiry into student engagement was a Grade VII classroom in a high school in the Montreal area. Approximately 1200 students populated the school ranging from grade VII to XI. To make the school welcoming for the younger students, the physical plant was organized as a "school within a school" (Sturge Sparkes \& Smith, 1998, p. 140). The Grade VII and VIII classes were housed in a separate wing of the building with their own administrative office.

The classroom being examined was a component of the Alternative Learning Program (ALP) offered in the school for about ten years. The program was designed to provide an enriched learning environment for students in Grades VII-IX. It was created to compete with the curriculum being offered in private schools. According to an information flyer, the program was "interdisciplinary" and "involved both experiential and cooperative learning with a strong emphasis on creativity." Photography, debating and computer technology were infused into the curriculum to enrich what was being offered. The aim of the program was to extend student learning beyond the classroom through visits to museums, art galleries, and other cultural venues.

Students wishing to enter the ALP in Grade VII were selected. They were required to submit an application and write an entrance exam. Recommendations from the staff of the feeder schools were also considered. Retention in the program was not automatic. Students were obliged to reapply in subsequent grades. It was not uncommon for students to be reassigned to "a non-ALP classroom" at the end of the first year.

The Grade VII group I studied was comprised of 28 students. The teacher, one of the key participants in my study, worked with the students in both English and French language arts. Within her classes, specific projects were completed in collaboration with colleagues in other curriculum areas. Classes were scheduled according to the language of instruction, one in English and one in French per day. For the remainder of the school day, students pursued other subjects. 


\section{Methodology}

My data emerged from a multiplicity of sources identified as primary, secondary and tertiary. Through "multi-sourcing" (Huberman \& Miles, 1998), I established Mathison's (1988) notion of constructing "plausible explanations about the phenomena being studied" (p. 17). Multi-sourcing seemed to be a viable way to build plausibility because it helped to "develop, question, refine, and/or discard interpretations [of the data] and the underlying perspectives they reflect" (Metz, 2000, Spring, p. 62-63).

The primary source was three-tiered: namely observation, reflective writings (submitted by all study participants), and interviews. With each activity, contact with the teacher and students intensified. Collection of observation data continued throughout the school year (September-May) based on, where feasible, one visit per week. I viewed the collecting process as an "emergent sequence" design in which the data garnered from one activity pointed to the next. The data gathered from September to January was used to set up the reflective writings completed in January. The reflective writings, in turn, were cues for the interview questions. The interviews, conducted primarily from March to May of the school year, were a venue for exploring in greater depth what had been expressed in the reflections. I continued to record field notes, even while conducting other data collecting activities. The notes were invaluable for reflecting upon what I was observing. To further validate my data, I observed classroom activities from January to June of the following school year. Caution, I realized, had to be exercised. Another group of students brought different dynamics to the classroom and subsequently to my study. Yet, in my view, the juxtaposition of the two groups brought clarity to my interpretations.

The secondary sources of data collection were two-tiered. The first tier comprised of information gathered from sources other than my own. Such data took the form of artifacts distributed in class, as well as samples of student work. The second tier emerged from the Student Engagement project, a pan-Canadian study involving ten schools from across the country of which my "host" school was a participant (Smith, Butler-Kisber, LaRocque, Portelli, Shields, Sturge Sparkes, \& Vibert, 1998). Through my involvement in the project, I had already built a rich bank of knowledge about the school and the community. Although I had agreed to keep my own research separate from the Student Engagement project, it was inevitable that one would spill into the other.

My tertiary source was another local public school with a strong fine arts focus. The subsidiary site was introduced not so much as a point of comparison but for providing another context against which my observations could be juxtaposed. 


\section{Study Findings}

My research suggests that, in the classroom, participation manifests itself in layers (Sturge Sparkes, 2005) reminiscent of Vibert and Shield's (2003) continuum. The first layer, I identify as "assigned participation" (p. 78). Student participation at this level occurs in learning situations in which classroom activities are largely "teacher initiated" (Mitra, 2003, p. 292). Teacher expectations propel student action, in both an individual and a collective sense. In short, students are often driven by the desire to please and to respond to the will of the teacher. Students displaying the characteristics of assigned participation are often learning in an environment in which, to quote McMahon (2003), "the teacher presents material in an interesting way or ... uses a variety of strategies to convey information that the teacher deems important" (p. 260). In my study, the distinction between the individual and the group learner is evident when students are complying with the teacher's aim to provide "individualized competition and cooperative groupings." Assigned participation encompasses student responses to the teacher's strategies to fulfill her goals.

The next layer I categorize as "shared participation" (p. 78). In this layer, students appear to be taking a more active role in their learning. Whereas in assigned participation, students express the desire to comply with teacher expectations; in the dimension of shared participation, students are complying to a will of their own. Many in-class activities remain teacher-driven, yet students appear to be taking greater initiative by voicing opinions and making suggestions that the teacher takes seriously (Rudduck \& Dimetriou, 2003). Behaviors displayed in the classroom suggest that "through active participation in knowledge production students [become] more involved in learning both the required and the other curriculum, and ... consequently learn more successfully" (Thomson \& Comber, 2003, p. 308). My observation aligns with Mitra's (2003) view that when a student has more control over her environment, she will feel more intrinsically motivated to participate.

A distinguishing feature in shared participation is the blurring between the learner as an individual and the learner as a group member. In keeping with hooks' (1994) holistic model of learning, there is evidence in this layer of stronger interaction among the students and the teacher, and less adherence to demarcation of roles.

In my study, some of the data revealed something else about participation. The data did not fit under participation as action, yet gave another dimension to my understanding of what I was seeing. The data spoke to me of an aspect of participation less tangible as it were, but very present. I could see it in the behaviors. I could 
hear it in the words. There was a spirit there: that intangible feeling that made life in this particular classroom so special. The classroom appeared as a space where, to quote Palmer (1998), "the human soul does not want to be fixed, it wants simply to be seen and heard" (p. 151). Participating, beyond action either assigned or shared, exudes an emotive condition or state in which both students and teacher freely share of themselves. The space of learning plays out Jardine's (1998) words that,"none of us necessarily knows all by ourselves the full contours of the story each of us is living out" (p. 47). Sharing seems to go beyond merely exchanging ideas. The ambiance of the classroom embodies Kessler's (2000) phrasing of a meaningful connection, that is, "respect and care that encourages authenticity for each individual in the group" (p. 22). The presence of such a connection surrounds the action in the form of a dynamic or quality I categorize as "participative tone."

The tenor of the classroom, both seen and felt, speaks to Smith et al.'s (1998) notion of "full participation", that is the linkage between engagement in learning and understanding of the "other" in the school community context (p. 125). Members of that community strive to construct Wyness' (2000) view of a micro-society, a place where both teacher and student can draw on a variety of social strategies to feed their own learning. There is a fit between affirmation of one's own abilities and affirmation of the abilities of colleagues (Rudduck \& Demetriou, 2003; Kessler, 2000). The students in my study were able to articulate what this meant to them.

And so I turn to the students for what they had to say. In their personal reflections and their interviews, the students revealed many things. Like Nieto (1994), I was "surprised at the depth of awareness and analysis" (p. 397) the students shared with me. They told me how they felt and at the same time pointed to what it was about their classroom that made them feel that way. In a sense what they told me was their story, certainly not in its complete form. But their words gave me tremendous insights into what life was like for them, at least their life in school. And in its own way, their story, even stories, gave me an inkling of where they wanted to go in the greater scheme of things. When presented with the opportunity, they had much to say. I reflect back upon Miriam Toew's (2001) interview with Leslee Silverman, artistic director of Winnipeg's Manitoba Theatre for Young People. In this interview Silverman states, "The universe is not made up of atoms, it's made up of stories" (p. 66). The remainder of this paper is dedicated to theirs. 


\section{Student Views of Participation}

In the study I categorized student thoughts about participation in three data clusters: being active, being challenged, and being energized. As a point of clarification, to protect student identity, I have used the first initial of their names only.

\section{Being Active}

This cluster was of particular interest to me because the word "active" linked directly with my first research question. Although students did not use these words, a number of them differentiated between active and non-active learning, showing a strong preference for the former. "We take part in what we do. We have to take part," was P.'s response to the question about participation.

Some students referred to participative learning in terms of physical engagement. "We do things," stated A., emphasizing the word "do." It was clear that "doing" went beyond being confined to desks. "I like being in the ALP," penned one student, "because instead of just sitting around working, we do all kinds of stuff." "There's always participation," volunteered J. stressing the word "always" as she spoke. "You just don't sit there." L. described the learning as being a "body" experience."It's very physical. You're not just sitting there reading out of a book." In keeping with the category title, one of the male students used the verb "act" in his response. "We get to act stuff out," declared G.

Other classmates, talked about participation in terms of an emotional commitment. "Participate? It means we really enjoy it, like wanting to fit in; wanting to do things," declared A. "We learn to think really quick," offered S., "just yell it out! It's fun to participate." R. affirmed ...

Everyone gets pumped up to do stuff. People don't sit in the corner and say, "This is so cheesy!" [She later explained to me that "cheesy" means, "It's so corny; so immature, so embarrassing..."]. Two more say, "It's so not boring" and five more say, "It's so fun." Everyone gets so hyper. We all want to do it.

Another student, M., added the dimension of sharing and collaboration to participation by introducing the descriptor "interactive." When pressed to tell me what she meant by the words, she replied, "Working together. Doing things that are 'hands on." J. added, "We get to know people more. Last year you tended to work 
alone. We move in groups." A. concurred that, "You interact with the teacher and therefore understand more. We express how we feel to classmates. We teach each other."

The students in my research had a sense of two kinds of learning. In contrast to what they were experiencing in the ALP classroom, non-active learning was often referred to as boring. "Other programs are really boring. They're not interesting," J. declared. "You don't really care what goes on." One student spoke of this type of learning as "plain learning." "It's much better than plain learning," declared S., "which can be pretty boring." In contrast to what they were doing in this course, J. referred to classes in previous years as being "normal." When I asked for clarification he explained "normal" as being "like last year. We didn't do anything special. We just worked."

Some students were very clear about what "plain" or "normal" learning entailed: Nieto's (1994) "chalk and talk" kind of learning where the teacher was heavily reliant on textbooks and blackboards (p. 405). "In another class nothing is fun," exclaimed J., "The teacher talks and talks and talks and gives us stencils." Students assured me that this was not the case in this classroom. "We do extra without sticking to the book," A. informed me. "We do different work in different ways," another colleague conceded.

\section{Being Challenged}

Some students described participation in terms of engaging in things that were challenging. They initially talked about it in their personal reflections. When the word was used, the students portrayed it in a positive light. M. wrote this comment in her reflection, "I think the ALP is a great program. This is because the students that want more of a challenge in their work can have it." T. raised this point:"I thought the work was going to be really hard, but it's not; it's just challenging like any work should be." The statement signaled to me that in his mind, at least, there was a decided difference between work that was "challenging" and work that was "hard."

I felt this point was significant and required further investigation. When I raised the issue in the focus groups, S. compared a challenge to a "mystery puzzle." "You have to try to figure it out. You have to think it through." A colleague explained the difference in this fashion:"Challenging is you have to put your mind to it but you can do it. Hard ... you put your mind to it but you can't figure it out." Other students added an emotional perspective to the difference between the two. "If I find something challenging," declared L., "I enjoy learning about it. If it's hard 'it's a drag'!" R., another classmate, responded to the question with these words ... 
If something is a challenge I feel I can get excited about it. I'm more up to it. If it's hard, I get frustrated. I'm pulling my hair out. "Oh no," I say to myself,"I can't do this!"You want to beat the challenge. If it's hard you feel you can't get it.

Some students described a challenge as being something they could deal with on their own.G. talked about a challenge as "something that may be hard at first, but if it's challenging, we can do it ourselves." A colleague in the same focus group echoed these sentiments. K. stated that "challenging is something I want to work on on your own, like fractions. It's hard at first, but after working on it you can say, 'I've got it!" "Doing for yourself" was particularly appealing if the challenge was accompanied by choice. M. intimated that "if you find something hard you find it frustrating. If something is a challenge you have choices." T. explained ...

I like a good challenge because I want to do for myself. When I'm obligated to do something I don't want to do it as much. For example, in our debating I got to choose a topic I was interested in.

A number of students identified a task as a challenge if it connected with what they already knew. K. described a challenge as "you know it but you know you have to work towards it." A colleague, M., added to the discussion that when something is a challenge, "you build on experiences to try new stuff." Other students talked about challenge as building the capacity for future learning. J. stated, "I find that challenges make us work harder and work faster. It's improving how we work."

The comments showed the depth of understanding these students had about their learning. Even though they were unable to articulate the concept using "academic" language, they were, in my view, talking about metacognition, Nelson's (1999) notion of having "a feeling of knowing" (p. 626) or the "aboutness" of knowing (p. 625). Students seemed to feel that challenges were significant signposts to becoming better learners.

Some students, appearing to have an awareness of metacognition, voiced that challenges are not something to be avoided but to be welcomed. In one interview, R. appraised the English language arts course as one in which challenge was fun. "Challenging is drama," she conceded, "Freeze [a drama exercise played in the class] is thinking on your feet. You're having fun at the same time. Hard is 'I don't want to be doing this!'" "It's a good opportunity," surmised A., "If you don't get challenges you will not learn as much." 


\section{Being Energized}

A number of the students described participating as involvement requiring a high energy level. In her personal reflection, R. wrote, "I really enjoy English [language arts] because it is extremely exciting. With debating, Shakespeare and drama, there is never a dull moment. After watching/listening to everyone around you, some of their enthusiasm is most likely to rub off on you." In their interviews, various classmates confirmed R.'s point of view. When asked to produce one word to describe the English language arts course, J. replied, "Energetic!" Another student, T. exclaimed, "Spontaneity!"

To some students, the fast pace of the course energized them. One student, whose name was not identified, wrote that in the course,"you get to go on many field trips; you learn very fast; you have fun with your friends; and you do lots of activities in the class." Various colleagues agreed. When asked to comment on a statement made in one of the personal reflections, B. explained, "I don't think we do it better. We do the same things as students in the regular program but we probably do it faster." "We work quicker than other classes," declared I. A colleague, however, took exception to the word "quicker" asserting that, "I would say rather than quicker we do it more efficiently. It doesn't take us as long to do it." A., I felt, encapsulated best his classmates' thoughts on this issue ...

We go through things more quickly. We do a lot of work. We're always moving on to new things. It never gets boring. We're never dragging through the same thing ...

In whatever way they defined it, students seemed to see participation as something that could not be done half-heartedly or apathetically. Participating, to some of them at least, demanded high energy and considerable commitment.

\section{Student Views of Participation: A Summary}

The students added to my understanding of participation, and, ultimately, of engagement. In their words I saw glimpses of assigned participation for both the individual learner and the group learner. I saw references to individual development of skills such as gathering information and questioning as well as the group perspectives of being on task and soliciting interaction. Interestingly, in their eyes participation seemed to be thought of as something unfolding more deeply: what I have 
identified as shared participation. There was a strong sense of engagement. Students were involved because they wanted to and not because they had to. They were actors rather than passive observers of their learning. In a nutshell, they owned their learning.They had high expectations for what they wanted to get out of the learning experience. They were highly challenged and even energized by what they were doing. Most importantly, they expressed participation in terms of an emotional investment aligning with, but even adding to, my discussions of participative tone. The repeated use of the pronoun "we" in their statements affirmed this assertion.

\section{Recent Student Voices}

Understandings of engagement expressed by students in my study were confirmed in recent exchanges with students participating in various arts projects under the banner of ArtsSmarts. The ArtsSmarts program, funded over the last seven years by the McConnell Family Foundation, provides funding to schools to employ local artists to work collaboratively with classroom teachers. The aim of the program is to enable the artist and the teacher to develop and to implement an arts experience in the classroom curriculum.

A few months ago, I spoke with a student about her involvement in the ArtsSmarts project taking place in her elementary school. She described her learning as something she had separated into two distinct camps: the "usual" way and the "project" way. I asked her which way she preferred. Her eyes lit up as she responded, "Oh, this [the project] way, of course, because we all get to work together." In using the word "all," she was including the teachers, as well as the artists. It was amusing that during one of my visits to the same class, the teacher had to "order" students, who were working in self-selected groups on various dimensions of the project, to take their recess. Engagement, indeed!

The dancer described in the prologue, was a participant in an ArtsSmarts project in a regional high school. After observing the session, I met with the teacher who coordinated the project. She shared with me some of the reflections students had written about their experience. Students talked about the "endless possibilities of dancing" and what they had shared with each other. A colleague declared that, "This is not work for us" and further explained that the art experience exuded a passion that connected with their real lives. A senior student wrote wistfully that this is a second experience with an ArtsSmarts project; and that,"I wish I was in secondary school again next year to participate in another." 
The words of the students call us to examine the role that the arts, and, in particular, the creative dimension of the arts, play in nurturing student engagement. The connection is well documented (Carley, 2005; Covington Soul, 2002; Eisner, 2002; Greene, 2000; May, 1991; Smithrim \& Upitis, 2005). It is, however, a discussion that warrants considerable attention not possible within the confines of this paper. Suffice it is to say, that in my own research, the arts need to take their rightful place in our organizations of learning. If they do not, the education we offer our youth is incomplete, even, if I might boldly declare, profoundly impoverished.

\section{Epilogue}

Engaged in their learning, students position themselves as both knower and actor. They move through the continuum: from resistance to compliance to collaboration, and on to self-liberation. "To know" in some detached sense is clearly not enough. In their voices, students reveal that meaning is embedded in context and derived from their own perceptions of what it is to learn. They acknowledge that "to know" in the truest sense is to engage in the simultaneous act of "pluralizing and individualizing the ways of knowing" (Gardner, 1991, p. 80). Students express this understanding. They unwrap the paradox. By accepting the multiplicity of knowledge, they embrace its peculiarity. They step into its dance with wonder and with joy.

\section{References}

Carley, M. (2005). Creative learning \& living: The human element. Montreal, QC: Thomas More Institute Papers.

Covington Soul, K. (2002). Multi-genre case studies. In E. Mirochnik \& D. Sherman (Eds.), Passion and pedagogy (pp. 401-418). New York: Peter Lang.

Eisner, E. (2002). The arts and the creation of mind. New Haven, CT:Yale University Press.

Gardner. H. (1991). The unschooled mind. New York: BasicBooks.

Greene, M. (2000). Imagining futures: The public school and possibility. Journal of Curriculum Studies, 32(2), 267-280. hooks, b. (1994). Teaching to transgress: Education as a practice of freedom. New York: Routledge.

Huberman, M., \& Miles, M. (1998). Data management and analysis methods. In N. Denzin \& Y. Lincoln (Eds.), Collecting and interpreting qualitative materials (pp. 179-210). Thousand Oaks, CA: Sage.

Jardine, D. (1998). To dwell with a boundless heart: Essays in curriculum theory, hermeneutics, and the ecological imagination. New York: Peter Lang.

Kessler, R. (2000). The soul of education. Alexandria, VA: Association for Supervision and Curriculum Development (ASCD). 
May, W. (1991). The arts and curriculum as lingering. In G. Willis \& W. Schubert (Eds.), Reflections from the heart of educational inquiry: Understanding curriculum and teaching through the arts (pp. 140-152). Albany, NY: State University of New York Press.

Mathison, S. (1988). Why triangulate? Educational Researcher, 12(2), 13-17.

McMahon, B. (2003). Putting the elephant into the refrigerator: Student engagement, critical pedagogy and antiracist education. McGill Journal of Education, 38(2), 257273.

Metz, M. (2000, Spring). Sociology and qualitative methodologies in educational research. Harvard Educational Review, 70(1), 60-74.

Mitra, D, (2003). Student voice in school reform: Reframing student-teacher relationships. McGill Journal of Education, 38(2), 289-304.

Nelson, T. (1999). Cognition versus metacognition. In R.Sternberg (Ed.), The nature of cognition (pp. 625-641). Cambridge, MA: The MIT Press.

Nieto, S. (1994). Lessons from students on creating a chance to dream. Harvard Educational Review, 64(4), 392-427.

Palmer, P. (1998). The courage to teach: Exploring the inner landscape of a teacher's life. San Francisco: Jossey-Bass.

Rudduck, J. \& Dimetriou, H. (2003). Student perspectives and teacher practices. McGill Journal of Education, 38(2), 274-287.

Smith, W., Butler-Kisber, L., LaRocque, L., Portelli, J., Shields, C., Sturge Sparkes, C., \& Vibert, A. (1998). Student engagement in learning and school life: National project report. Montreal, QC: Office of Research on Educational Policy, McGill University.

Smithrim, K., \& Upitis, R. (2005). Learning through the arts: Lessons of engagement. Canadian Journal of Education 28, 1\&2, 109-127.

Sturge Sparkes, C. (2005). Being and becoming an 'I want to learn person': Participating in an arts-oriented learning environment: Perception and context. Unpublished doctoral dissertation, McGill University, Montreal.
Sturge, Sparkes, C., \& Smith, W. with L. ButlerKisber \& R. Peera (1998). Part II: Quebec. In W. Smith, H. Donahue, \& A. Vibert, Student engagement in learning and school life: Case reports from project schools, Vol. II (pp. 95-185). Montreal, QC: McGill University, Office of Research on Educational Policy.

Thomson, P., \& Comber, B. (2003). Deficient 'disadvantaged students' or media-savvy meaning makers? Engaging new metaphors for redesigning classrooms and pedagogies. McGill Journal of Education, 38(2), 305-328.

Toews, M. (2001, January). Child's play. Enroute, 61-66.

Vibert, A., Shields, C. (2003), Approaches to student engagement: Does ideology matter? McGill Journal of Education, 38(2), 221-240.

Wyness, M. (2000). Contesting childhood. London, UK: Falmer. 


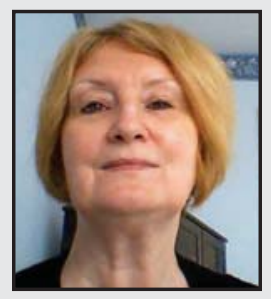

Carolyn Sturge Sparkes, PhD., brings to the field of educational research expansive experience as a teacher, consultant and workshop facilitator, particularly in the areas of music and arts-integrated education. In more recent years, she has been an active proponent of school improvement and has been instrumental in assisting school boards and schools develop their plans for success. She has published a number of articles relating to this topic. Carolyn's career as an educator extends from her native province of Newfoundland and Labrador and, in more recent years, to the province of Quebec. Carolyn was awarded a doctorate in Education from McGill University in 2005. She now resides in Qualicum Beach, British Columbia where she continues to pursue new career directions especially related to her two primary passions: fine arts education and writing. 